\title{
The Country of Origin and Brand Image Effect on Purchase Intention of Smartphone in Surabaya - Indonesia
}

\author{
DiyahTulipa \\ Email:d_tulipa@yahoo.com \\ Ninuk Muljani \\ UnikaWidya Mandala Surabaya
}

\author{
Doi:10.5901/mjss.2015.v6n5s5p64
}

\begin{abstract}
At present, borderless among countries makes international companies spread their business all over the world. Goods that produced in one country are being sold in other countries. This phenomenon forces global marketers to understand factors that influence consumers' evaluation on a product. Consumer buying behavior on global brand mostly based on extrinsic information. Evaluation on a product is conducted by perception to brand (Brand Image) and country where the product is manufactured (Country of Origin). This study examined the effect of country of origin and brand image on consumers' purchase intention of smartphone in Surabaya and employed 150 visitors of smartphone trade centre in Surabaya. Structural Equation Modeling (SEM) was applied to measure the relationships among constructs. The data analysis is performed by Analysis of Moment Structure (AMOS Graph version 16). The results of this study showed that country of origin have an influence on brand image and attitude. Brand image have an effect on attitude and purchase intention. Subjective norm have an influences on purchase intention. Otherwise, attitude does not have an effect on purchase intention. This study supports the idea that extrinsic information (country of origin and brand image) has an effect on attitude and purchase intention.
\end{abstract}

Keywords: country of origin, brand image, subjective norm, attitude, purchase intention.

\section{Introduction}

In today's, development of technology and communication lead increasing on smartphone competition. This phenomenon makes marketers tries to understand how consumers buy a smartphone. Marketers who understand their consumers can create better products and services and develop strategies in order to gain competitive advantage (Kardes et al., 2011:11). Consumers' evaluation on products and services are based on intrinsic information such as content and design of product or extrinsic information which is price or brand or country of origin (Lee, 2013). Country of origin is defined as a country where the product is manufactured. According to Lee (2013) consumer mostly focus on extrinsic information of country of origin when they buy a global brand. The development of global companies and global branding makes country of origin being a consumers' focus on global product evaluation (Bhakar et al., 2013).

Consumers' perception on product and services are various. For example, consumers in developed countries prefer the domestic product compare to the product from developing countries because they seek for quality. In other hand, consumers in developing countries prefer to buy a product that produced by developed countries because they see a brand as a tool to increase their social status (Kawabata, 2009 in Lee, 2013). The same product that produced by a countries is perceived differently. Thus, it is clear that country of origin has influence on consumers' evaluation on product.Country reputation effects brand image (Godey et al., 2010).

Based on Lee (2013), at present in global market provide a various product that produced by developing countries. Smartphone is one of global brand that produced in one country and being sold in other countries. Most of countries that produced smartphone are developing country, namely China. One of the aims of the study is to investigate the influence of country of origin related to brand image.

Extrinsic information such as brand image affects consumers purchase decision making. Simamora (2004) defined brand image as a perception or an association of the thoughts and feeling that consumers have about a brand. Consumer evaluates the brand based on their experience with the brand. A good perception on a product affects a positive attitude toward product. In contrast a bad perception of a product affects a negative attitude toward product. Attitude toward a product related to a certain behavior can be explained use Theory of Reasoned - Action/TRS (Azjen 
and Fishbein, 1980).

TRA is a consumer behavior formula that includes two main factors those are attitude and subjective norm. First component relate to consumers believe toward the product that evaluated. Believe as an evaluation result affects consumer attitude toward the product that leads to purchase behavior. Second component is consumer belief toward their social environment includes friends, family member and other social groups. Decision to purchase a product is influence by social environment.

This study is conducted based on the paradigm that Smartphone is being a global brand and in Surabaya there is a lot of brand that came from various countries, both developed and developing countries.

\section{Literature Review}

\subsection{Country of Origin (COO)}

Hsieh (2004) states that definition of $\mathrm{COO}$ is classified in to three groups including country image, product class related to certain country and product or brand related to a country. Consumer mostly rely their evaluation of brand based on COO as extrinsic information before consumer decided to buy a product. Country image as an item evaluation is important for consumer since consumer evaluation on product is not only based on value or quality of product but also based on what country that produced the product, how it produced and who made the product. Consumer consider ethical to choose the product. Moreover, at the era of global brand and mushrooming of global company that operates crossover among countries makes $\mathrm{COO}$ being an important component on product evaluation (Lee, 2013). COO as an item of evaluation is being a consumer consideration not only in developing countries but also in developed countries (Bilkey and Nes, 1982).

Studies on COO related to purchase decision making are conducted by Bhakar et al. (2013) and Lee (2013). Yasin et al. (2007) in Permana (2013) states that COO is measured by country innovation in production, advance of technology, product design, creativity, product quality, country prestige level and country image.

$\mathrm{COO}$ is consumers' perception toward country reputation that produced a product. A good country reputation such as a country that known has high technology capabilities is perceived that the country's product has a good products' quality. Study conducted by Permana (2013) showed that COO has a positive influence on brand image. Therefore, hypothesis proposed which is related to $\mathrm{COO}$ and brand image is:

$\mathrm{H} 1$ : Country of Origin has a positive influence with brand image.

Studies on $\mathrm{COO}$ shows that development of global brand leads to $\mathrm{COO}$ as a factor that considered by consumer on purchase decision making (Lee, 2013). They consider where the product came from. If the product came from the country with a good reputation, most of consumers will have a positive attitude toward the product. On the other hand, if the product came from non reputable country, consumer will have a negative attitude toward the product. Thus, COO as an object of product evaluation configure consumers' attitude. The result of the study by Li et al. (2007) in Bhakar et al. (2013) showed that COO have a significant relationship with attitude on consumer purchase of imported product. The hypothesis proposed related to $\mathrm{COO}$ and attitude is:

$\mathrm{H} 2$ : $\mathrm{COO}$ has a positive influence with attitude.

\subsection{Brand Image}

Keller (2008:51) defined brand image is reflection of brand association based on consumers' memories towards product. Association of brand that memorized by consumer can figure brand image. Consumers' memory could be access at a right time and figure a certain image of brand. This is a brand positioning on consumers mind that will be well memorized as top of brand. Theresults of study by Yuliani (2012) shows that brand image have an influence on product decision making. Amanah (2011) and Permana (2013) studies' also show that brand image have an effect on consumer purchase decision making. Permana (2013) measured brand image by strong brand, brand reputation, corporate image, user image and product image.

Brand is product identity. Consumer may have a good or bad perception on product. Brand as an object of evaluation determine consumers' attitude towards a product. A good image of product will lead to positive attitude towards product. In contrast, a bad image of product will lead to negative attitude towards product. Chung (1977) in Bhakar et al. (2013) states that brand has a specific impression and could configure consumers' attitude towards brand. Therefore, a hypothesis proposed in this study is:

$\mathrm{H} 3$ : Brand image has a positive influence with attitude. 
Consumer usually confuse when they are facing the similar product on market. Limited time to search an information make them have a limited information as a basis for choosing a product. Consumer often used brand image to make a purchase decision. Moreover, consumers are like to purchase well-known brand because they believe that the product can satisfy them (Bhakar et al, 2013). The argument is supported by the result of the study by Bhakar et al (2013) that brand image is an antecedent of purchase intention. Therefore, a hypothesis proposed related to brand image and purchase intention is:

$\mathrm{H} 4$ : Brand image has a positive influence with purchase intention

\subsection{Attitude}

Attitude is defined as consumers' feeling about an object (Schiftman and Kanuk, 2007). These feelingsare like or dislike toward an object that emerge when consumer make an evaluation on an object.Then, consumer decides whether he/she like or dislike the object Therefore, it is clear that attitude has an object to evaluate.Attitude is a new beginning of consumer behavior process.

Attitude is not permanently and could change but attitude is consistent and have the same likelihood. Time have no significant influence on attitude changes. The changes of an attitude mostly affects by situational factors. Canniere et al. (2009) used excited, important, practice, good idea, precious, good, fascinating as indicators to measure attitude.

Consumers' evaluation on product leads to attitude towards product, whether consumer like or dislike the product. The result of the evaluation will be memorized. A good memory of a product will configure positive attitude towards product. Attitude towards product will be remains on consumer memory as an intention. In a perfect time, intention will become a behavior (Azjen 2005:99). Canniere et al (2009) study's shows that consumer's attitude has an influence to consumer purchase intention. Thus, hypothesis proposed related to attitude and purchase intention is:

H5: Attitude has a positive influence with purchase intention.

\subsection{Subjective Norm}

Subjective norm refers to consumers' perception on social pressure that influences how consumer makes a decision (Canniere et al., 2009) such as friends, family members, colleagues and kids. Measuring of subjective norm is focus on people around. Canniere et al (2009) used family members, friends and colleagues as indicators to measure subjective norm.

Consumers' purchase behavior mostly based not only on personal want but also influences by social pressure such as family members, friends and colleagues. They believe that their closed person may perform a favor certain behavior and their beliefs influence their behavioral intention (Pavlou and Chai, 2002 in Yang and Jolly, 2009). The result of the study on behavioral intention show that subjective norm have influence on repurchase intention (Canniere et al., 2009). The hypothesis proposed related to subjective norm and purchase intention is:

H6: Subjective Norm has a positive influence with purchase intention.

\subsection{Purchase Intention}

Azjen (2005:99) state that intention is willingness that stored in human memory and will lead to an action on perfect time. It is need a trigger to change intention to an action. Intention remains in human memory until there is a right time and chance to perform behavior.Behavior intention is one of main factors that configure behavior (Azjen, 1991). Intention defined as motivation that affects behavior. The stronger intention leads to stronger behavior. Thus, intention can be understood as an expression before perform an action. Intention has dependently with time. Since there is a long distance time between intention and action then the intention will weak. Azjen (2005) measured intention with three indicators those are when, where and how consumer will perform their future behavior.

\section{Research Method}

\subsection{Participant}

This study involved 150visitorsof smartphonetrade center in Surabaya Indonesia. Most of samplearemen(59,33\%) with the most age range from 20 -34 years old. Characteristics of respondent are presented in Table 1. 
Table 1. Participant Characteristics

\begin{tabular}{lcc}
\hline & Numbers ( $\mathrm{N}=150)$ & Percentage \\
\hline Gender & & \\
Males & 80 & 59.33 \\
Females & 61 & 40.66 \\
Age & & \\
$20-34$ years old & 76 & 50.67 \\
$35-54$ years old & 49 & 32.67 \\
$55-65$ years old & 25 & 16.66 \\
Occupation & & \\
Students & 21 & 14.00 \\
Employees & 75 & 50.00 \\
Housewives & 15 & 10.00 \\
Entrepreneurs & 39 & 26.00 \\
\hline
\end{tabular}

\subsection{Measures}

Each construct was measured using 5-point Likert scale, ranging from 1 (completely disagree) to 5 (completely agree). Each indicator was adopted from previous study (Azjen, 2005; Canniere et al, 2009; Permana, 2013). Five constructs were applied to the model of visitor's experiences those are country of origin (4 indicators), subjective norm (3 indicators), brand image (5 indicators), attitude (6 indicators) and purchase intention (6 indicators).

Country of Origin $\left(X_{1}\right)$ is consumer's perception regarding origin country's reputation and ability to produce smartphone (Hsieh, 2004). There were 4 indicators used to measure country of origin: country innovation in production, advance of technology, product design, creativity, product quality, country prestige level and country image (Yasin et al., 2007). There were 4 items used to measure country of origin (e.g. I consider country of origin reputation to choose a smartphone)

Subjective Norm $\left(\mathrm{X}_{2}\right)$ is the influences of family members, friends and colleagues that have an impact on purchase decision making of smartphone (Canniere et al., 2009). 3 indicators were applied to measure subjective norm: family members, friends and colleagues (Canniere et al., 2009).There were 3 items used to measure subjective norm (e.g. I consider the favor of my friends in choosingsmartphone).

Brand Image $\left(\mathrm{Y}_{1}\right)$ is consumer's perception regarding brand reputation and strong brand of the smartphone (Keller, 2008). There were 5 indicators used to measure brand image: strong brand, brand reputation, corporate image, user image and product image (Permana, 2013). There were 5 items used to measure brand image (e.g. I choose smartphone with well-known brand)

Attitude $\left(Y_{2}\right)$ is consumer's feeling (like or dislike) toward smartphone (Schiffman and Kanuk, 2007). Six indicators were applied to measure attitude: exciting, important,a good idea, good for me, pleasant and handy (Caniere, et al., 2009). There were 6 items used to measure attitude (e.g. Buy a smartphone that has a good brand reputation is a good idea)

Purchase Intention $\left(Y_{3}\right)$ is consumer willingness to purchase smartphone in the future (Azjen, 2005). Measurement purchase intention by 6 items (e.g. I intent to buy smartphone that came from reputable country)

\subsection{Procedures}

The study was conductedonone smartphone center in Surabaya Indonesia. There were 150 samples size applied.The interviewswere conductedatthe exit since the goalisto interviewvisitorafter they weresearched information at the outlets. Theinterviews wereconductedon weekdays (Monday - Friday)andon weekends (Saturday and Sunday) related to the busy days whenmore visitors coming. In orders to get the right respondent, the criterionset forthe respondentswas customerswhovisitedsmartphone trade centerat least2timesin thelast 2 months.

\subsection{Statistical Analysis}

Data were processed based on the principles of inferential descriptive statistics. Structural Equation Modeling (SEM) by using AMOS and SPSS programs were applied to prove hypotheses. 


\section{Results}

Test of outliers, validity and reliability were conducted in order to confirm that data supported further analysis. Outlier was examined by Mahalanobis Distance, cut-off is $51.178(\mathrm{p}=0.001, \mathrm{df}=24)$. The results show that there were four respondents (2.67\%) whose answers were beyond the normal distribution. Since the number less than $4 \%$ all data used for further analysis.

The assessment of convergent validity of each indicator used factor loading. The standardized factor loading ranged from .408 to .814 . These results show that every item is valid. Composite reliability was used in assessment of reliability. The composite reliability for each construct ranged from 0.628 to 0.804 . These results show that all constructs are reliable. Table 2 presented a summary of the reliability and validity data.

Table 2. Assessment of Reliability and Validity for All Construct in the Model

\begin{tabular}{lcccc}
\hline Latent Constructs & Indicators & Factor Loadings & Composite Reliability & \\
\hline \multirow{2}{*}{ Country of Origin } & 1 & .534 & & Valid \\
& 2 & .651 & & Valid \\
& 3 & .679 & & Valid \\
& 4 & .615 & & Valid \\
Subjective Norm & 1 & .714 & & Reliable \\
& 2 & .751 & & Valid \\
& 3 & .814 & & Valid \\
Attitude & & & & Valid \\
& 1 & .593 & .804 & Reliable \\
& 2 & .581 & & Valid \\
& 3 & .535 & & Valid \\
& 4 & .610 & & Valid \\
& 5 & .535 & & Valid \\
& 6 & .484 & & Valid \\
Brand Image & & & & Valid \\
& 1 & .513 & & Reliable \\
& 2 & .474 & & Valid \\
& 3 & .552 & & Valid \\
& 4 & .581 & & Valid \\
& 5 & .419 & & Valid \\
& & & & Valid \\
Purchase Intention & 1 & .577 & & Reliable \\
& 2 & .542 & & Valid \\
& 3 & .600 & & Valid \\
& 4 & .587 & & Valid \\
& 5 & .520 & & Valid \\
& 6 & 0.408 & & Valid \\
& & & & Valid \\
& & & & Reliable \\
\hline
\end{tabular}

Structural equation modeling was applied to test hypotheses. The fit statistics of the structural model showed good fit and moderate fit, $X^{2}(245 \mathrm{~N}=150)=590.163 ; X^{2} / \mathrm{df}=2.409 ; p<.001 ; \mathrm{CFI}=.833 ; \mathrm{GFI}=.777 ; \mathrm{RMSEA}=.097$. Path coefficients for structural equation modeling are shown in Figure 1. 


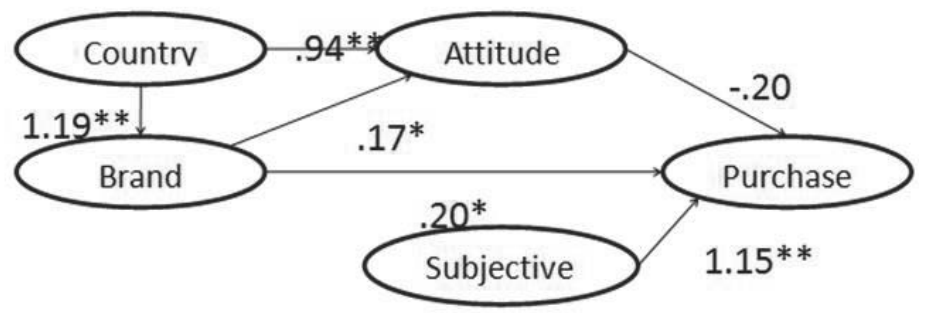

Figure 1. Path Coefficient of Structural Model of country of origin, subjective norm, brandimage, attitude and purchase intention.

Numbers represent standardized coefficients * $(p<.05)$

Numbers represent standardized coefficients $* *(p<.001)$

Complete hypothesis test results can be seen in Table 3. Specifically $\mathrm{H}_{1}$ to $\mathrm{H}_{6}$ are:

$\mathrm{H}_{1}$ stated that country of origin will have relationship with brand image. In line with $\mathrm{H}_{1}$, the result shows that country of origin has a significant effect on brand image $\left(\gamma_{1}=1.19, \mathrm{p}<.001\right)$, so $\mathrm{H}_{1}$ was supported. This result confirms previous study by Bhakar et al. (2013) and Permana (2013). Consumer perceived that smartphone from reputable country has a good brand image. They believe that country with a good reputation will make a good product too. Besides, consumer also perceived that the good country reputation and country image means a good product.

Related to country of origin, $\mathrm{H}_{2}$ predicted that country of origin will have effect with attitude. As hypothesized, country of origin has a significant effect on attitude $\left(\beta_{1}=0.94, p<.001\right)$. Thus, $\mathrm{H}_{2}$ was supported. Country of origin is an extrinsic information that used by consumer to evaluate product. As an object of evaluation,country of origin influence attitude which is consumer's feeling (like or dislike) to an object.

$\mathrm{H}_{3}$ predicted that brand image will have effect with attitude. These results also indicate that brand image has significantly relationship with attitude $\left(\beta_{2}=0.17, \mathrm{p}<.05\right)$. Thus, $\mathrm{H}_{3}$ was supported. Brand also as an extrinsic information that used by consumer to evaluate smartphone. On the other hand, attitude need object to evaluate which is brand image. So, since consumer perceived that smartphone has good brand image such as reputable brand or strong brand then consumers will have positive attitude to smartphone brand. Moreover, a good image of corporate, user and product will lead consumer to have a positive attitude to smartphone brand.

The other hypothesis related to brand image is $\mathrm{H}_{4}$ that predicted brand image will have effect with purchase intention. In line with $\mathrm{H}_{4}$, the result shows that brand image has significant effect on purchase intention $\left(\beta_{3}=0.20, p<.05\right)$, so $\mathrm{H}_{4}$ was supported. Consumer perceived if they buy smartphone that has good brand image will satisfy them. Besides, consumer reduces risk by choosing well-known smartphone.

$\mathrm{H}_{5}$ stated that attitude will have effect with purchase intention. The result of this study was not supported $\mathrm{H}_{5}\left(\beta_{4}=\right.$ $.20, n . s)$. Relationship between these constructs was not significant. Consumer's attitude toward smartphone that they were seen in outlets will not give an influence to purchase intention. If it is compare to another antecedent of purchase intention (e.g. subjective norm - see test result $\mathrm{H}_{6}$ ), this result give an understanding that attitude cannot be used to predict purchase intention since the consumer's evaluation to purchase intention focus on group favor.

Table 3. Hypotheses Test

\begin{tabular}{lllll}
\hline Hypotheses & Constructs & \multicolumn{3}{c}{ Path Coefficient } \\
\hline $\mathrm{H}_{1}$ : Country of origin will have relationship with brand image & Country of origin $\rightarrow$ brand image & $\gamma_{1}$ & $1.19^{\star *}$ & Supported \\
$\mathrm{H}_{2}$ : Country of origin will have relationship with attitude & Country of origin $\rightarrow$ attitude & $\beta_{1}$ & $0.94^{* *}$ & Supported \\
$\mathrm{H}_{3}$ : Brand image will have relationship with attitude & Brand image $\rightarrow$ attitude & $\beta_{2}$ & $0.17^{*}$ & Supported \\
$\mathrm{H}_{4}$ : Brand image will have relationship with purchase intention & Brand image $\rightarrow$ purchase intention & $\beta_{3}$ & $0.20^{*}$ & Supported \\
$\mathrm{H}_{5}$ : Attitude will have relationship with purchase intention & Attitude $\rightarrow$ purchase intention & $\beta_{4}$ & -0.20 & Not Supported \\
$\mathrm{H}_{6}:$ Subjective norm will have relationship with purchase intention & Subjective norm $\rightarrow$ & $\gamma_{1}$ & $1.19^{* *}$ & Supported \\
\hline
\end{tabular}

${ }^{* \star} p<.001,{ }^{*} p<.05$ 
$\mathrm{H}_{6}$ predicted that subjective norm will have effect with purchase intention. As hypothesized, the result shows that subjective norm has a significant relationship with purchase intention $\left(\gamma_{2}=1.15, p<.001\right)$. Thus $\mathrm{H}_{6}$ was supported. A group of social pressure including family members, friends and colleagues could influence consumer's purchase behavior. The favor of these groups becomes the favor of individual since he/she wantsto be accepted by the group.

\section{Conclusion}

This study supports the idea that extrinsic information (country of origin and brand image) has an effect on attitude and purchase intention. Consumer's evaluation on global brand mostly based on extrinsic information. Country of origin and brand image is considered as an object of evaluation. Consumer with a good perception on country of origin and brand image will have a good evaluation on product that evokes a positive attitude toward product. As an object of evaluation, country of origin also has a direct influence on attitude. Reputable country will lead consumers to have positive attitude on product. In line with country of origin that has direct effect on attitude, country of origin also have direct effect on brand image. Consumer perceived that reputable country makes good product. Thus, good country means good brand image. Consumer with a good brand image will have an intention to buy the product.

This study also supported that social norm has an influences on purchase intention. This result gives an understanding that social group favor becomes personal favor in that group. Family members, friends and colleagues influences purchase behavior.

It is interesting to note that attitude did not have an influence on purchase intention. Consumer with a positive attitude toward product does not have an intention to buy the product. Compare to other antecedent of purchase intention in this model (brand image and subjective norm), this phenomenon can see that consumers mostly buy the product because of prestige. Consumer evaluated the product based on an image which is brand image and feel that he/she belongs to the group so he/she has to buy the product same as the group favor. Consumer was regardless personal favor.

Limitation of this study is research setting which is only limited for one smartphone trade center. In aims to generalize the results,replication of the studyshould be conductedinother smartphone trade center.

\section{References}

Amanah, D. (2011). PengaruhPromosidan Brand Image (Citra Produk) terhadapPembelianProdukPepsodent di Ramayana Plaza JalanAksara Medan. JurnalKeuangandanBisnis, Volume 3 No. 3, November 2011.

Azjen, I. (2005). Attitude, Personality and Behavior.Open University Press.

Azjen, I.(1991). The Theory of Planned Behavior.Organizational Behavior and Human Decission Process 50, 179-211.

Bhakar, S.S., Bhakar, S\&Bhakar, S. (2013). Relationship Between Country Of Origin, Brand Image and Customer Purchase Intention. Far East Research Centre.

De Cannière, M. H., De Pelsmacker, P\&Geuens, M.(2009).Relationship Quality and the Theory of Planned Behavior Models of Behavioral Intentions and Purchase Behavior.Journal of Business Research, 62, 82-92.

Ferdinand, A. (2002). Structural Equation ModellingdalamPenelitianManajemen.Aplikasi Model-Model RumitdalamPenelitianuntukTesis Magister danDisertasiDoktor.Edisi 2.Semarang : BP UniversitasDiponegoro.

Godey, B., Pederzoli, D., Aiello, G.,Donvito, R., \&Wiedmann, K.P. (2010). Luxury Brand and Country of Origin Effect : Results of an International Study. Journal of Marketing Trends, 1,1, 67-75.

Hair J.F., Rolp, A., Black, W.C., Babin, B.J.,\& Anderson, L., E. (2010).Multivariate Data Analysis A Global Perspective. $7^{\text {th }}$ Edition. New Jersey : Pearson Prentice Hall.

Hsieh, M.H. (2004). An Investigation of Country of Origin effect using correspondence analysis : A Cross-national context. International Journal of Market Research, 46(3), 267-295.

Kardes, F.R., Cline, T.W., \&Cronley, M.L.(2011).Consumer Behavior : Science and Practice. International Edition.South Western Cencage Learning.

Lee, L.(2013). The Relationship netween Global Brand and Country of Origin in Chinese Consumption Market.International Review of Business, 13:87-112. 2013.

Permana, M.S. (2013). Pengaruh Country of Origin, Brand Image dan Persepsi KualitasTerhadap Intensi Pembeli an pada Merk.Skripsi. Fakultas Ekonomik adan Bisnis. Universitas Kristen Satya Wacana Salatiga.

Schiffman, L.G., \&Kanuk, L.L.(2007).Consumer Behavior, third edition, Engelwood Cliffs, New Jersey, Prentice-Hall.Inc.

Yang, K., \& Jolly, L. D. (2009). The effects of consumer perceived value and subjective norm on mobile data service adoption between American and Korean consumers. Journal of Retailing and Consumer Services, 16(6) 